\title{
Acute liver injury
}

\author{
I. C. TALBOT
}

From the Department of Morbid Anatomy, King's College Hospital, London'

During metabolism in the liver the concentration of a drug or its metabolic products may be locally increased. This provides a theoretical basis for the large and ever-increasing number of reports of acute liver damage following drug therapy. If a drug or its metabolic product is a cellular poison we may expect a direct hepatotoxic reaction with a constant relationship to the level of drug in the serum and consequently with a relationship to the dose, ie, predictable liver injury (Scheuer, 1973).

\section{Predictable Acute Liver Injury}

Thanks to careful testing of new drugs before release by the manufacturers few drugs in use today cause predictable acute liver injury in normal dosage. Chloroform is a well known example of an obsolescent drug which predictably results in fatty change and, in more severe cases, acute necrosis of the liver. Amongst currently used drugs there have been instances of hepatic necrosis following antibiotics used in cancer chemotherapy (Ream, Perlia, Wolter, and Taylor, 1968; Moertel, Reitemeier, and Hahn, 1968), but the most significant example of predictable acute hepatic failure following normal therapeutic dosage of a drug is the acute fatty liver which occasionally complicates tetracycline therapy during pregnancy or in patients with impaired glomerular filtration. The reaction is predictable to the extent that it is dependent on the serum concentration of tetracycline (Whalley, Martin, Adams, and Combes, 1970). Deepening jaundice and hepatic precoma and coma are fortunately rare events with this drug, being limited to those patients in whom impaired renal excretion can lead to abnormally high serum tetracycline levels.

Paracetamol, the widely used analgesic, predictably produces acute liver injury when taken in suicidal overdose. After an initial two to three days' period of irritability, which may be mistaken for hysteria, jaundice and other signs of acute liver failure appear. By the fourth day the liver becomes

'Present address: The Pathology Department, St Mark's Hospital, City Road, London, EC1V 2PS tender and histologically shows a uniformly distributed centrilobular coagulative necrosis (fig 1). In the early stages there is also vacuolation of adjacent surviving hepatocytes. Out of 200 patients admitted to the Liver Unit at King's College Hospital with signs of liver damage following an overdose of between 10 and $100 \mathrm{~g}$ of paracetamol, 29 died in fulminant hepatic failure (Portmann, Talbot, Day, Davidson, Murray-Lyon, and Williams, 1975).

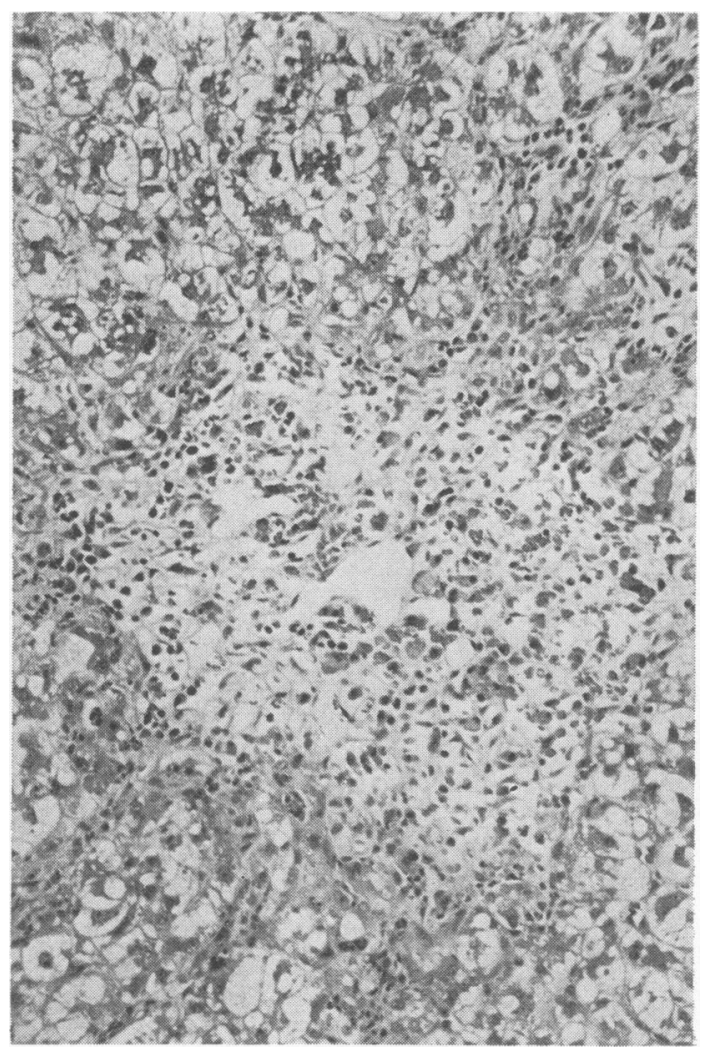

Fig 1 Coagulative necrosis of centrilobular liver parenchyma seven days after paracetamol overdose. Surviving hepatocytes contain fine vacuoles (needle biopsy, $H E \times 450)$. 
Predictable acute liver poisoning by a drug, although dose-related, may be potentiated by such factors as stress, pregnancy, malnutrition, alcohol and other drugs. The liver injury appears after a short, constant latent period. Such toxic effects are reproducible in animals. These criteria, however, do not apply to the majority of instances of druginduced acute liver damage, the manifestations of which are unpredictable.

\section{Unpredictable Acute Liver Injury}

Unpredictable drug reactions are, by definition, inconstant, occurring in only a small proportion of individuals exposed to the drug in question. Signs of liver damage appear after a variable latent period of up to three weeks. The severity of damage is variable, but may be great and is unrelated to dosage. The nature of the acute liver injury associated with a particular drug may vary from one patient to another, but in an individual patient unpredictable acute liver injury falls into one of three broad categories, namely, cholestatic hepatitis, acute hepatitis and severe hepatic necrosis.

\section{CHOLESTATIC HEPATITIS}

In these cases jaundice dominates the clinical picture with conjugated hyperbilirubinaemia and raised serum transaminase levels. Histologically in the liver there is bile retention, predominantly centrizonal, in hepatocytes as well as in canaliculi. Single cell necrosis is seen in the parenchyma with acidophil bodies, but this is not a prominent feature. Portal tracts are infiltrated by lymphocytes and sometimes by eosinophils. A variant of this, following therapy with the long-acting sulphonamide combination, co-

\begin{tabular}{|c|c|}
\hline Drug & Reference \\
\hline $\begin{array}{l}\text { Chlorpromazine } \\
\text { Trifluoperazine (Stelazine) } \\
\text { Chlordiazepoxide }\end{array}$ & $\begin{array}{l}\text { Cheongvee, Hurst, and Smith (1967) } \\
\text { Kohn and Myerson (1961) } \\
\text { Lo, Eastwood, and Eidelman (1967) }\end{array}$ \\
\hline Tolbutamide & $\begin{array}{l}\text { Gregory, Zaki, Sarcosi, and Carey } \\
\text { (1967) }\end{array}$ \\
\hline Chlorpropamide & $\begin{array}{l}\text { Reichel, Goldberg, Ellenberg, and } \\
\text { Schaffner (1960) }\end{array}$ \\
\hline Dapsone & Millikan and Harrell (1970) \\
\hline Erythromycin estolate & Fischer and Hoak (1964) \\
\hline Mercaptopurine & $\begin{array}{l}\text { Shorey, Schenker, Suki, and Combes } \\
\text { (1968) }\end{array}$ \\
\hline Azathioprine & Sparberg, Simon, and Del Greco (1969) \\
\hline Amitriptyline & Morgan (1969) \\
\hline Phenobarbital & Pagliaro, Campesi, and Aguglia (1969) \\
\hline Oxyphenisatin & $\begin{array}{l}\text { Pearson, Grainger, Scheuer, and } \\
\text { MacIntyre (1971) }\end{array}$ \\
\hline Methyldopa & $\begin{array}{l}\text { Toghill, Smith, Benton, Brown, and } \\
\text { Matthews (1974) }\end{array}$ \\
\hline Chloramphenicol & Gjone and Orning (1966) \\
\hline Sulphamethoxazole & Perez, Schaffner, and Popper (1972) \\
\hline Diazepam & Perez, Schaffner, and Popper (1972) \\
\hline
\end{tabular}

Table I Drugs associated with cholestatic hepatitis and representative documentary sources

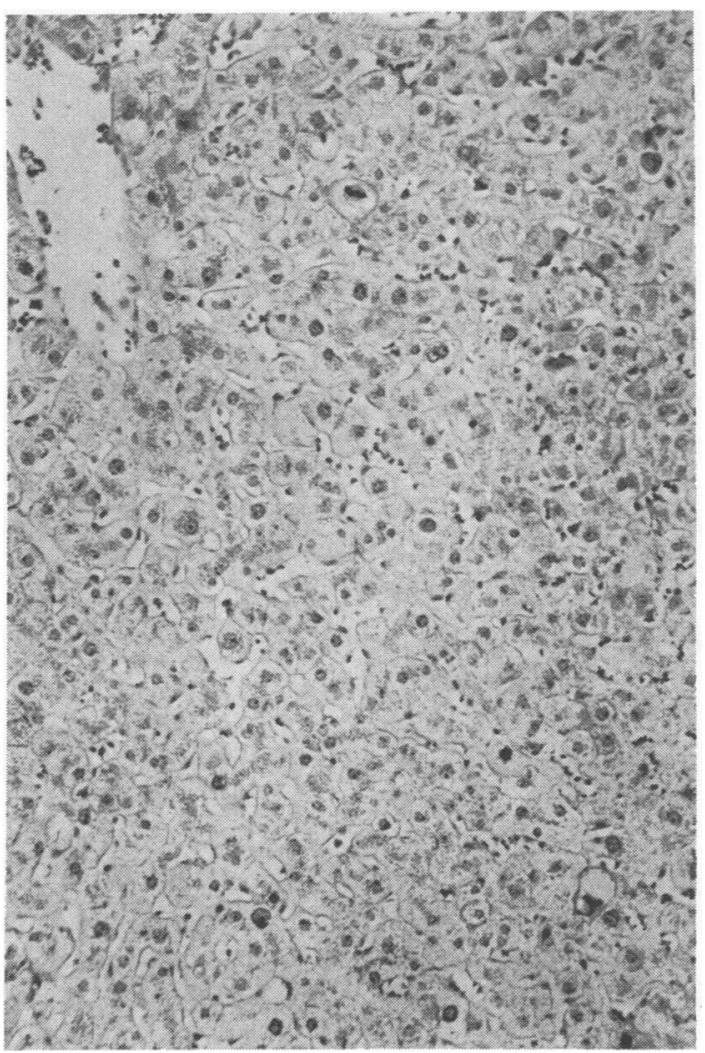

Fig 2 Intracellular bile pigment in a patient with cholestatic hepatitis following treatment with co-trimoxazole (Septrin). Single necrotic hepatocytes (acidophil bodies) and mitotic figures are randomly scattered in the parenchyma (needle biopsy, $H E \times 450$ ).

trimoxazole (trimethoprim + sulphamethoxazole, Septrin) is shown in figure 2. The more commonly used drugs with which this type of cholestatic hepatitis reaction has been described are listed in table I.

\section{ACUTE HEPATITIS}

Here the clinical picture is similar to viral hepatitis with fever, malaise and nausea, with or without jaundice. The serum transaminases are raised. Histology of the liver, exemplified in a patient with an adverse reaction to methyldopa, shows 'spotty' necrosis with acidophil bodies in the parenchyma, swelling of Kupffer cells and infiltration of portal tracts by a variable mixture of lymphocytes, plasma cells and eosinophils (fig 3). Table II lists the more widely used drugs with which this viral-hepatitis-like reaction has been documented. 


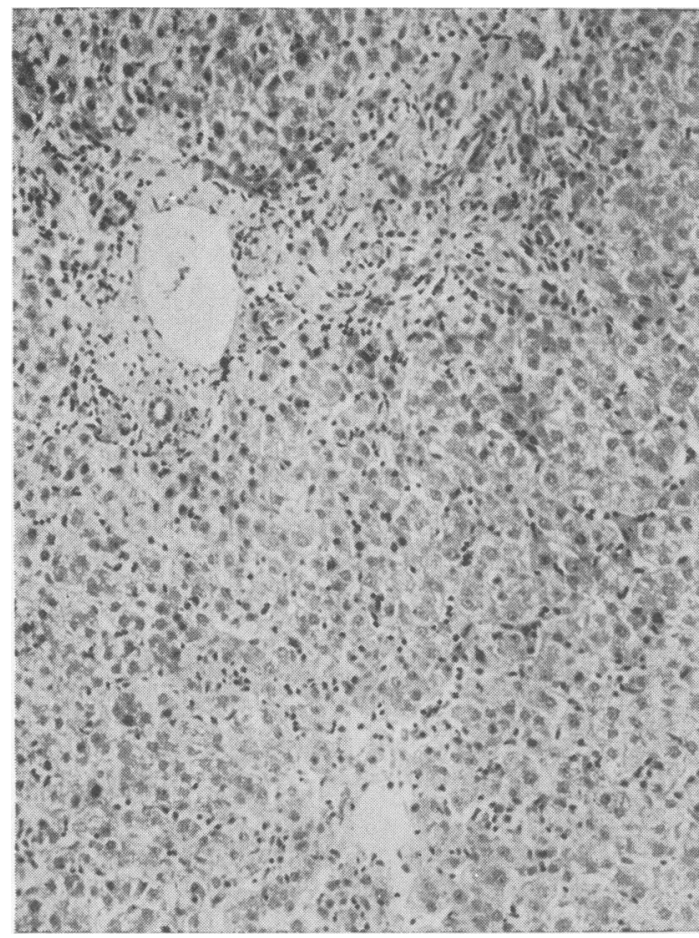

Fig 3 Acute hepatitic reaction to methyldopa. Acidophil bodies, clumps of lymphocytes and swollen Kupfer cells mark foci of 'spotty' parenchymal necrosis. The slightly expanded portal tract contains lymphocytes and plasma cells (needle biopsy, $H E \times 450)$.

\begin{tabular}{|c|c|}
\hline Drug & Reference \\
\hline Methyldopa & $\begin{array}{l}\text { Toghill, Smith, Benton, Brown, and } \\
\text { Matthews (1974) }\end{array}$ \\
\hline Rifampicin and isoniazid & $\begin{array}{l}\text { Lal, Singhal, Burley, and Crossley } \\
\text { (1972) }\end{array}$ \\
\hline Rifampicin & $\begin{array}{l}\text { Scheuer, Summerfield, Lal and Sher- } \\
\text { lock (1974) }\end{array}$ \\
\hline Isoniazid & Maddrey and Biotnott (1973) \\
\hline $\begin{array}{l}\text { Phenindione } \\
\text { Sulphamethoxazole (Septrin) }\end{array}$ & Mohamed (1965) \\
\hline $\begin{array}{l}\text { Sulphamethoxazole (Septrin) } \\
\text { PAS }\end{array}$ & Dujovne, Chan, and Zimmerman (1967) \\
\hline PAS & $\begin{array}{l}\text { Fulkerson, Husen, Lieberman, and } \\
\text { Stein (1969) }\end{array}$ \\
\hline $\begin{array}{l}\text { Ethionamide } \\
\text { Ethacrynic acid }\end{array}$ & Conn, Binder, and Orr (1964) \\
\hline Ethacrynic acid & $\begin{array}{l}\text { Datey, Deshmukh, Dalvi, and } \\
\text { Purandere (1967) }\end{array}$ \\
\hline $\begin{array}{l}\text { Diphenylhydantoin } \\
\text { Carbamazepine }\end{array}$ & Pezzimenti and Hahn (1970) \\
\hline $\begin{array}{l}\text { Carbamazepine } \\
\text { Phenylbutazone }\end{array}$ & Ramsay (1967) \\
\hline $\begin{array}{l}\text { Phenylbutazone } \\
\text { Indomethacin }\end{array}$ & Ecker (1965) \\
\hline $\begin{array}{l}\text { Indomethacin } \\
\text { Clindamycin }\end{array}$ & Ferich, Bannister, and Grech (1967) \\
\hline Clindamycin & $\begin{array}{l}\text { Elmore, Rissing, Rink, and Brooks } \\
\text { (1974) }\end{array}$ \\
\hline $\begin{array}{l}\text { Colchicine } \\
\text { Papayerine }\end{array}$ & Borurchow (1966) \\
\hline Papaverine & Ronnov-Jessen and Tzernlund (1969) \\
\hline
\end{tabular}

Table II Drugs associated with acute hepatitic reaction mimicking viral hepatitis with representative documentary sources
SEVERE HEPATIC NECROSIS

Here, after a variable latent period of up to three weeks, the patient becomes restless and may develop the picture of fulminant hepatic failure, rapidly passing into hepatic coma. Jaundice often appears later, together with evidence of blood coagulopathy with widespread bruising and haemorrhage. Liver histology shows sharply circumscribed confluent parenchymal necrosis, approximately related to the central parts of the lobules. The surrounding hepatocytes are often vacuolated and contain fat. In the more severe and fatal cases there is submassive or massive hepatic necrosis. Such a histological picture, in a case of fulminant hepatic failure following halothane anaesthesia, is illustrated in figure 4. The drugs with which this type of severe reaction has been described are listed in table III.

In the case of halothane a causal relationship between its use in anaesthesia and subsequent severe hepatic necrosis has been difficult to establish, despite numerous retrospective investigations, and has been the subject of much controversy (Sharpestone, Medley, and Williams, 1971; Simpson, Strunin, and Walton, 1971). The incidence of jaundice after multiple exposures to halothane was estimated by Mushin, Rosen, and Jones (1971) to be between 1 in 6000 and 1 in 22000 anaesthetics. Of 31 patients with liver necrosis following halothane exposure admitted to King's College Hospital over four years up to 1974 , there were 16 deaths. This corresponds closely to the $51 \%$ mortality recorded by Inman and Mushin (1974) using data from the Committee on Safety of Medicines. McPeek and Gilbert (1974) rightly pointed out that similar reactions occur after other anaesthetic agents with unknown incidence, possibly as frequently as with halothane, and that retrospective surveys based on voluntary reporting of cases are inevitably biased. Nevertheless, in the 15 cases of post-halothane liver necrosis from the King's College Hospital series from which histology is available, similar features to those illustrated in fig 4 are seen in all, to a lesser or greater degree, and there can be little doubt that this kind of reaction,

\begin{tabular}{|c|c|}
\hline Drug & Reference \\
\hline Halothane & $\begin{array}{l}\text { Peters, Edmondson, Reynolds, Meister, } \\
\text { and Curphey (1969) }\end{array}$ \\
\hline $\begin{array}{l}\text { Monoamine oxidase } \\
\text { inhibitors } \\
\text { Imipramine }\end{array}$ & $\begin{array}{l}\text { Holdsworth, Atkinson, and Goldie } \\
\text { (1961) } \\
\text { Powell, Koch-Weser, and Williams } \\
(1968)\end{array}$ \\
\hline $\begin{array}{l}\text { Pyrazinamide } \\
\text { Cyclophosphamide }\end{array}$ & $\begin{array}{l}\text { Brincourt and Teyssier (1968) } \\
\text { Aubrey (1970) }\end{array}$ \\
\hline
\end{tabular}

Table III Drugs associated with severe hepatic necrosis/fulminant hepatic failure with representative documentary sources 


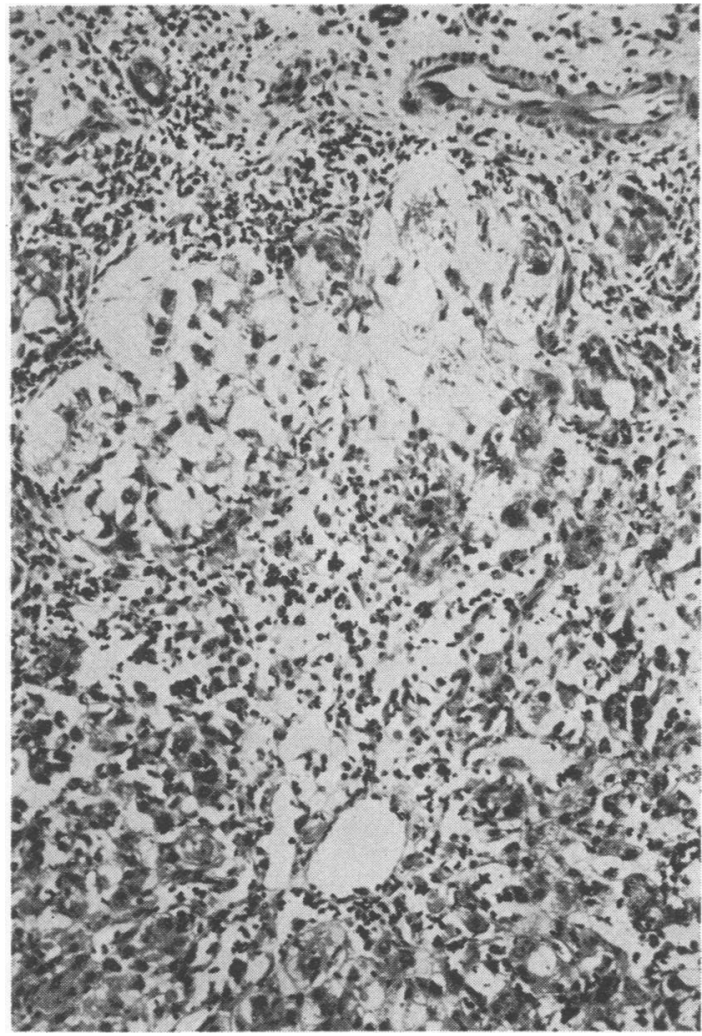

Fig 4 Submassive hepatic necrosis seven days after the fourth halothane anaesthetic within nine months. The centrilobular necrosis is less well circumscribed than in paracetamol overdose (see fig 1). Periportal hepatocytes, at the top of the field, are swollen and vacuolated.

The lymphocytic infiltrate is not specific and could be secondary to liver cell destruction. (Postmortem needle sample, $H E \times 450$ ).

although rare, does occur. What is in doubt is its incidence relative to that of similar reactions with other anaesthetics. Until a prospective survey has established these statistics there is no evidence to suggest that halothane is a comparatively hazardous anaesthetic agent (British Medical Journal, 1974).

\section{Difficulties in Attributing Acute Liver Injury to a Particular Drug}

Unpredictable injury is not usually reproducible in animals. The liver injury following exposure to halothane illustrates the difficulty of closing the gap between suspicion and proof in implicating an unpredictable drug reaction as the cause of liver injury; the number of individuals exposed to the drug is almost always unknown and as these reactions are infrequent it is difficult to estimate their incidence. In many cases, such as with rifampicin, it is usual for the patient to have had a multiplicity of drugs, and not only may it be difficult to decide which drug is responsible, but interactions of combinations of drugs on the liver can give surprising and paradoxical results (Berthelot, 1973) It should also be remembered that patients receiving drugs are no less likely than others to develop viral hepatitis. This is particularly so in the case of drug addicts.

\section{Criteria for Acceptance of Drug Toxicity as the Cause of Acute Liver Injury}

1 Viral hepatitis and vascular disturbances, eg, hypotensive shock, should as far as possible be excluded.

2 As soon as a drug is suspected of causing liver damage it should be withheld from the patient; most signs and symptoms of acute liver injury will then subside provided that the patient is not in fulminant hepatic failure. The ultimate test of drug hepatotoxicity is that the condition recurs on challenge with the drug (Perez, Schaffner, and Popper, 1972) but this is in many cases too hazardous to test.

3 Finally, any instance of unexplained acute liver disease requires documentation of all drug therapy given up to three weeks previously. If data from sufficient numbers of patients are collected a pattern of frequency of association with particular drugs may be built up. Then is the time to investigate the mechanisms involved.

\section{References}

Aubrey, D. A. (1970). Massive hepatic necrosis after cyclophosphamide (Letter). Brit. med. J., 3, 588.

Berthelot, P. (1973). Mechanisms and prediction of drug-induced liver disease. Gut, 14, 332-339.

Borurchow, I. B. (1966). Bone marrow depression associated with acute colchicine toxicity in the presence of hepatic dysfunction. Cancer (Philad.), 19, 541-543.

Brincourt, J., and Teyssier, L. (1968). Hépatites à évolution prolongée induiter par certains tuberculostatiques. Rev. Tuberc. (Paris), 32, 831-838.

British Medical Journal (1974). Leading article. Halothane and liver damage. Brit. med.J., 3, 589-590.

Cheongvee, E. M., Hurst, L., and Smith, R. H. F. (1967). Agranulocytosis and jaundice associated with chlorpromazine. Brit. J. clin. Pract., 21, 95-96.

Conn, H. O., Binder, H. J., and Orr, H. D. (1964). Ethionamide. induced hepatitis: a review with a report of an additional caseAmer. Rev. resp. Dis., 90, 542-552.

Datey, K. K., Deshmukh, S. N., Dalvi, C. P., and Purandare, N. M. (1967). Hepatocellular damage with ethacrynic acid. Brit. med. J., 3, 152-153.

Dujovne, C. A., Chan, C. H., and Zimmerman, H. J. (1967). Sulfonamide hepatic injury: review of the literature and report of a case due to sulfamethoxazole. New Engl.J. Med., 277, 785-788.

Ecker, J. A. (1965). Phenylbutazone hepatitis. Amer. J. Gastroent., 43, 23-29.

Elmore, M., Rissing, J. P., Rink, L., and Brooks, G. F. (1974). 
Clindamycin-associated hepatotoxicity. Amer. J. Med., 57, 627-630

Ferich, F. F., Bannister, W. H., and Grech, J. L. (1967). Hepatitis with biliverdinaemia in association with indomethacin therapy. Brit. med. J., 3, 155-156.

Fischer, H. W., and Hoak, J. C. (1964). Mimicry of acute cholecystitis by erythromycin estolate reactions. Amer. J. med. Sci., 247, 283-285.

Fulkerson, L. L., Husen, L. A., Lieberman, P., and Stein, E. (1969). Hypersensitivity, misdiagnosis and death in tuberculosis treated with para-aminosalicylic acid. N.Y. St. J. Med., 3045-3046.

Gjone, E., and Orning, O. M. (1966). Jaundice due to chloramphenicol Acta hepat.-splenol. (Stuttg.), 13, 288-292.

Gregory, D. H., Zaki, G. F., Sarcosi, G. A., and Carey, J. B., Jr. (1967). Chronic cholestasis following prolonged tolbutamide administration associated with destructive cholangitis and cholangiolitis. Arch. Path., 84, 194-201.

Holdsworth, C. D., Atkinson, M., and Goldie, W. (1961). Hepatitis caused by the newer amine-oxidase-inhibiting drugs. Lancet, 2 , $621-623$.

Inman, W. H. W., and Mushin, W. W. (1974). Jaundice after repeated exposure to halothane: an analysis of reports to the Committee on Safety of Medicines. Brit. med.J., 1, 5-10.

Kohn, N., and Myerson, R. M. (1961). Cholestatic hepatitis associated with trifluoperazine. New Engl. J. Med., 264, 549-550.

Lal, S., Singhal, S. N., Burley, D. M., and Crossley, G. (1972). Effect of rifampicin and isoniazid on liver function. Brit. med.J., 1, 148-150.

Lo, K. J., Eastwood, I. R., and Eidelman, S. (1967). Cholestatic jaundice associated with chlordiazepoxide hydrochloride (Librium) therapy. Amer.J. dig. Dis., 12, 845-849.

McPeek, B., and Gilbert, J. P. (1974). Onset of postoperative jaundice related to anaesthetic history. Brit. med. J., 3, 615-617.

Maddrey, W. C., and Boitnott, J. K. (1973). Isoniazid hepatitis. Ann. intern. Med., 79, 1-12.

Millikan, L. E., and Harrell, E. R. (1970). Drug reactions to the sulfones. Arch. Derm., 102, 220-224.

Moertel, C. G., Reitemeier, R. J., and Hahn, R. G. (1968). Mitomycin $\mathrm{C}$ therapy in advanced gastrointestinal cancer. J. Amer. med. Ass., 204, 1045-1048.

Mohamed, S. D. (1965). Sensitivity reaction to phenindione with urticaria, hepatitis and pancytopenia. Brit. med. J., 2, 14751476.

Morgan, D. H. (1969). Jaundice associated with amitriptyline. Brit. J. Psychiat., 115, 105-106.

Mushin, W. W., Rosen, M., and Jones, E. V. (1971). Post-halothane jaundice in relation to previous administration of halothane. Brit. med. J., 3, 18-22.

Pagliaro, L., Campesi, G., and Aguglia, F. (1969). Barbiturate jaundice: report of a case due to a barbital-containing drug, with positive rechallenge to phenobarbital. Gastroenterology, $56,938-943$.

Pearson, A. J. G., Grainger, J. M., Scheuer, P. J., and McIntyre, N. (1971). Jaundice due to oxyphenisatin. Lancet, 1, 994-996.

Perez, V., Schaffner, F., and Popper, H. (1972). Hepatic drug reactions. In Progress in Liver Diseases, edited by $\mathrm{H}$. Popper and $\mathrm{F}$. Schaffner, Vol. 4, pp. 597-625. Grune and Stratton, New York.

Peters, R. L., Edmondson, H. A., Reynolds, T. B., Meister, J. C., and Curphey, T. J. (1969). Hepatic necrosis associated with halothane anesthesia. Amer. J. Med., 47, 748-764.

Pezzimenti, J. F., and Hahn, A. L. (1970). Anicteric hepatitis induced by diphenylhydantoin. Arch. intern. Med., 125, 118-120.

Portmann, B., Talbot, I. C., Day, D. W., Davidson, A. R., MurrayLyon, I. M., and Williams, R. (1975). Histopathological changes in the liver following a paracetamol overdose: correlation with clinical and biochemical parameters. J. Path., in press.

Powell, W. J., Jr., Koch-Weser, J., and Williams, R. A. (1968). Lethal hepatic necrosis after therapy with imipramine and desipramine. J. Amer. med. Ass., 206, 642-645.

Ramsay, I. D. (1967). Carbamazepine-induced jaundice. Brit. med. J., 4,155

Ream, N. W., Perlia, C. P., Wolter, J., and Taylor, S. G., III. (1968), Mithramycin therapy in disseminated germinal testicular cancer. J. Amer. med. Ass., 204, 1030-1036.

Reichel, J., Goldberg, S. B., Ellenberg, M., and Schaffner, F. (1960). Intrahepatic cholestasis following administration of chlorpropamide. Amer. J. Med., 28, 654-660.

Rønnov-Jessen, V., and Tjernlund, A. (1969). Hepatotoxicity due to treatment with papaverine. New Engl. J. Med., 281, 1333-1335.

Scheuer, P. J. (1973). Liver Biopsy Interpretation, 2nd ed. Bailliere Tindall, London.

Scheuer, P. J., Summerfield, J. A., Lal, S., and Sherlock, S. (1974) Rifampicin hepatitis: a clinical and histological study. Lancet, 1, 421-425.

Sharpstone, P., Medley, D. R. K., and Williams, R. (1971). Halothane hepatitis-a preventable disease? Brit. med. J., 1, 448-450.

Shorey, J. Schenker, S., Suki, W. N., and Combes, B. (1968). Hepatotoxicity of mercaptopurine. Arch. intern. Med., 122, 54-58.

Simpson, B. R., Strunin, L., and Walton, B. (1971). The halothane dilemma: a case for the defence. Brit. med. J., 4, 96-100.

Sparberg, M., Simon, N., and Del Greco, F. (1969). Intrahepatic cholestasis due to azathioprine. Gastroenterology, 57, 439-441.

Toghill, P. J., Smith, P. G, Benton, P., Brown, R. C., and Matthews, H. L. (1974). Methyldopa liver damage. Brit. med.J., 3, 545-548

Whalley, P. J., Martin, F. G., Adams, R. H., and Combes, B. (1970) Disposition of tetracycline by pregnant women with acute pyelonephritis. Obstet. and Gynec., 36, 821-826. 